\title{
Influence of Open-cut Mining on Wind System around Quarry
}

by Naohiro OTSUKA ${ }^{1}$ and Yoshinori SEKIMOTO ${ }^{1}$

1. Faculty of Engineering, Iwate University, Ueda, Morioka 020

It is considered that land deformation caused by open-cut mining influences on wind system around the quarry. Two case studies were conducted to investigate the change of wind system around the quarry.

The results are summarized as follows:

(1) Land deformations caused by open-cut mining were simulated with three dimensional computer graphics, and it became possible to forecast the changes of wind direction visually.

(2) By use of quantitative formula that showed the relationship between lay of land and wind direction frequency, it became possible to forecast the changes of prevailing wind direction and wind direction frequency quantitatively.

(3) It became clear that deforestation according to open-cut mining influenced on increase of wind speed around the quarry.

(4) In case A, the ridge of the quarry will be mined, it was forecasted that change of wind system affected on living environment a little.

(5) In case B, all over the mountain will be mined-out, it was forecasted that wind system around the quarry was changed widely.

KEY WORDS: Open-cut Mining, Land Deformation, Microclimate, Wind Direction, Wind Speed

\section{1. 緒言}

石灰石や碎石用原石などの露天採掘が大規模化するのに伴い, 採掘方式も大規模生産に適した方式への移行が進んでいる。すな わち，従来の山の片側斜面のみにベンチを構築する，いわゆる山 腹式ベンチカット工法から, 最初に山頂部に切羽を設け, 尾根を 越えて順次掘り下がる山頂式ベンチカット工法や, 原石山の頂上 部よりスライスダウン式に採掘を進めて山全体を取り去ってしま う全山開発方式などの採掘方式を採用する例がかなり増加してき ている。これらの採掘方式は, 初期投資は大きいが, 先行剝土が 行えること, 可採量が多く生産性が高いこと, 終掘後の残壁緑化 面が少ないことなどの利点を有する ${ }^{1)}$ 。しかし，このような大規 模な開発行為による森林の伐採や, 尾根, 山塊の切り取りなどの 結果生じる大幅な地形改変は, 周辺地域の環境に様々な影響を及 ぼしている。例えば, 動物や植物の生態系を破壊して生物を絶隇 の危機にさらしたり, 景観を阻害して住民との間に摩擦を生じた りしている。さらには, 周辺地域の微気候, 特に風向, 風速など の風体系に従前と異なる現象が生じ, 問題となっている例がみら

\footnotetext{
* 1993 年 4 月 5 日受付 6 月 25 日受理 資源 - 素材学会平成 3 年度 秋季大会扣よび平成 4 年度春季大会にて一部発表

1. 正会員 工博 岩手大学助教授 工学部建設環境工学科

2. 正会員 工博 岩手大学教授 工学部建設環境工学科

キーワード: 露天採掘, 地形改变, 微気候, 風向, 風速
}

れる。露天採掘に伴う森林の伐採や地形改変は, それまで風が吹 き込まなかった地域に風が吹き込むようになったり，風速が強く なったりすることによって, 農作物や住宅に被害をもたらす場合 がある。また, 風による直接的な被害ばかりでなく, 採掘場から 発生する粉じんの飛散や騒音の伝搬などによって生活にも影響を 及ぼし，思わぬ環境問題となっている例もみられる。

本研究は, このような露天採掘に起因する森林の伐採や地形改 変が, 周辺地域の風向, 風速などの風体系に及ぼす影響について 検討したものである。

\section{2. 風体系変化予測のプロセス}

国土の80\%近くが山地であり，地形も複雑なわが国では，狭い 地域の中でも気候がかなり違うことが経験的に知られている。気 候学の分野では, 数 $\mathrm{m}$ 数 $\mathrm{km}$ の範囲の気候を微気候といい, 地 形と密接な関係にあることが指摘されている ${ }^{2)}$ 。微気候の要素に は, 気温, 降水量, 気圧, 風, 日照, 日射などがあり, これらの うちでは風が最も重要な要素であるといわれている。それは, 風 の状態によって他の微気候要素の分布が左右されることが多いか らである。また, 微気候の因子としては, 微気候の要素の分布に 影響を与える地表の諸性質, すなわち, 海抜高度, 水陸分布, 地 表の状態 (起伏, 温度, 植生, 色など ), 斜面の傾斜, 付近の山 地の状態などがあげられている。 


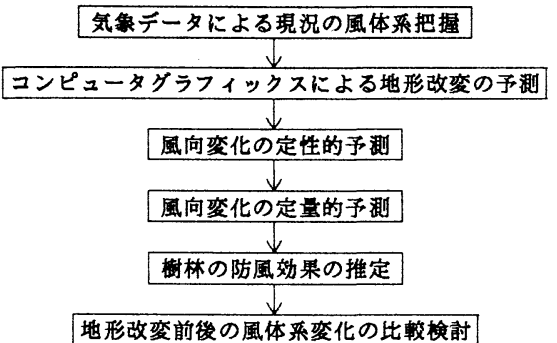

Fig. 1 Process of forecast for change of wind system.

露天採掘による森林伐採や地形改変は, 地表の状態, 斜面の傾 斜, 付近の山地の状態などの微気候の因子を大きく変化させる行 為であり，周辺地域の微気候に少なからぬ影響を及ぼすことが考 えられる。

以上のことから, 本研究では, 露天採掘に起因する微気候変化 を予測する方法として，地形と風との関係に焦点を絞り検討を行 った。Fig.1に風体系変化予測のプロセスを示す。その手順は, 以下のとおりである。

(1) 当該地域の気象観測所で観測された既往の気象データから 風配図，風速度数分布図を作成し，原石山周辺の現況の風体系を 把握する。

（2）開発計画図などに基づいて，コンピュータグラフィックス により鳥瞰図を作成し，地形改変状況を立体的にシミュレーショ ンする。これにより，地形と風向の関係を目視的，定性的に予測 する。

（3）地形と風向との関係を数量的に表現する方法を用いて，地 形改变前後の風向変化を定量的に予測する。

（4）原石山，特に稜線部が樹林で覆われている場合には，その 樹林が防風林として機能していることが想定されるので，伐採に よる風体系の変化，とくに防風効果の減衰を検討予測する。

（5）以上の結果をもとに，地形改変と風体系変化との関連を求 める。

\section{3. 既往の気象データによる現況の風体系}

本研究では，2 箇所の碎石山を事例として取り上げ検討した。 事例 A は, 宮城県石巻市の南東約 $2 \mathrm{~km}$ に位置する研石山を, 今 後 20 年間にわたり全山採掘方式で標高 $50 \mathrm{~m}$ レベルまで採掘を進め，その跡に得られる 約 20 万 $\mathrm{m}^{2}$ の造成地を公共用地として利用 しようとするもので，原石山の背後に山が ある例である。また，事例 B は，岩手県西 根町の北北西約 $1 \mathrm{~km}$ に位置する砕石山で, 原石山は平坦部に独立した山塊であり, 周囲 には平坦部に独立した山塊が点在している。 現在, 全山のほぼ半分が採掘されているが, 最終的には全山が採掘される予定である。

当該地域の現況の風体系を把握するため に，事例 Aでは原石山の南東約 $2 \mathrm{~km}$ ，事 例 $\mathrm{B}$ では北西約 $3 \mathrm{~km}$ の地点にある気象観 測所の過去 3 年間の観測データをもとに, 風配図および風速度数分布眓を作成した。

Fig. 2，Fig.3 は，事例 A, Bの月別 風配図のうち季別の代表例を示したもので ある。両事例とも冬期は北西方向，夏期は 南東方向の風が卓越しており，春と秋には
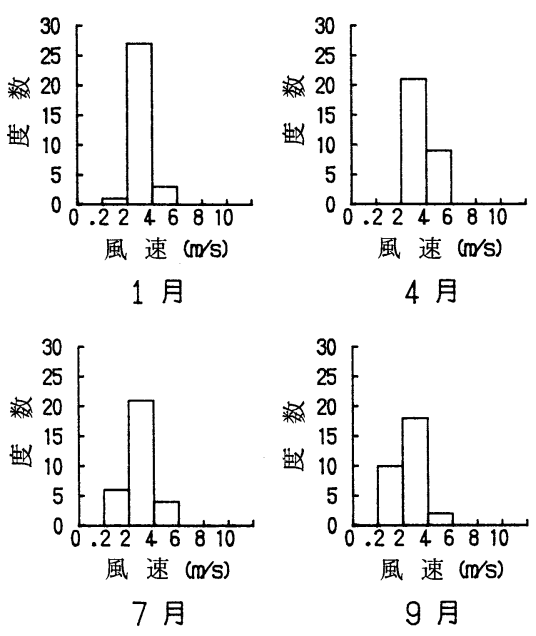

1989 年

Fig. 4 Example of histogram of wind speed for each season. (Case A)
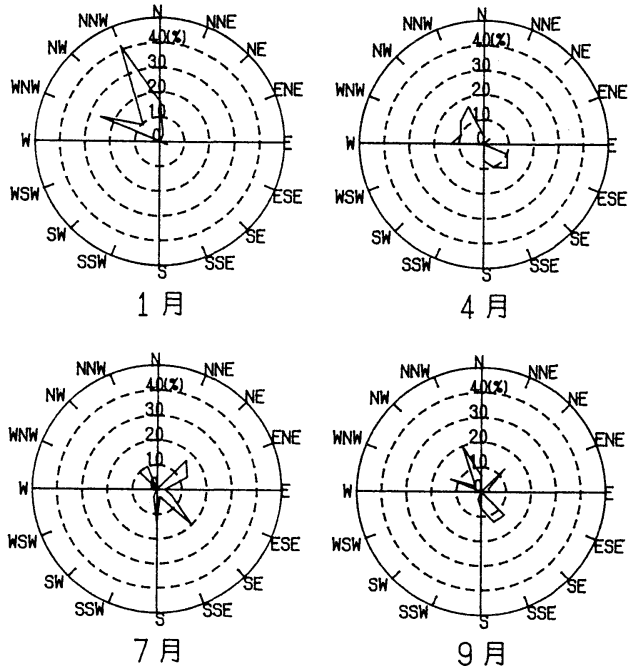

1989 年

Fig. 2 Example of wind rose for each season. (Case A)
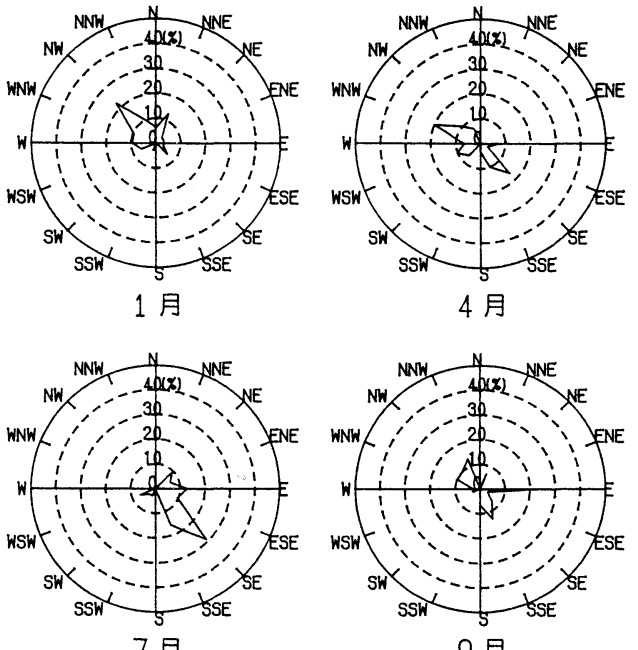

9 月

1990 年

Fig. 3 Example of wind rose for each season. (Case B)
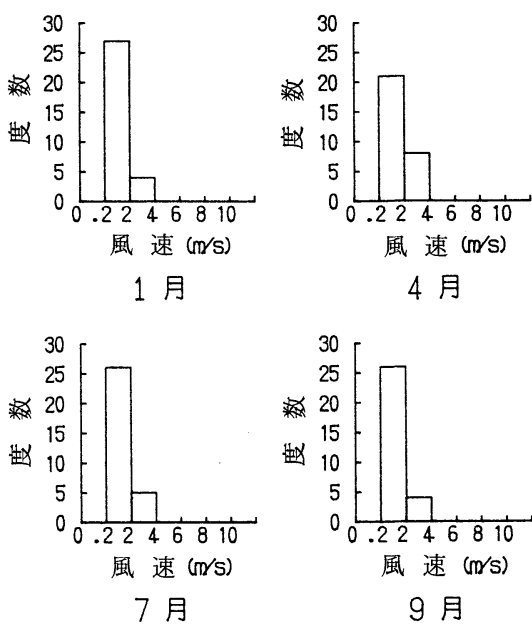

1990 年

Fig. 5 Example of histogram of wind speed for each season. (Case B) 
それらの風向が相半ばする傾向がみとめられる。

Fig.4，Fig.5は，事例 A, Bの月別風速度数分布の5ち季 別の代表例を示したものである。事例 $A$ では $2 \sim 4 \mathrm{~m} / \mathrm{s}$, 事例 B では $0.2 \sim 2 \mathrm{~m} / \mathrm{s}$ の度数が高く, 年間を通じて微風の日が多いよ うである。なお, 春先に事例 $\mathrm{A}$ では $10 \mathrm{~m} / \mathrm{s}$ 超光る南風分, 事例 $\mathrm{B}$ では $8 \mathrm{~m} / \mathrm{s}$ 程度の西風が吹く日が通常，年に数日みられる。

事例 A は海に面した位置に，また，事例 B は内陸に位置するが， ともにこれまで風による被害はほとんどみられない。

\section{4. 採掘前後の鳥瞰図による風体系变化の予測}

Fig.6,Fig.7は, 今回事例として取り上げた A, B 2 箇所 の砕石山の採掘前後の状況を, コンピュータグラフィックスによ る鳥瞰図で表したものである。これらのコンピニータグラフィッ クスは，採拙場を含む対象地域のメッシュ標高データによる 3 次 元数值地形モデルを，任意の視点を想定して，透視図でディスプ レイする方法 ${ }^{3) 4)}$ を用いて作成したものである。なお, メッシュ

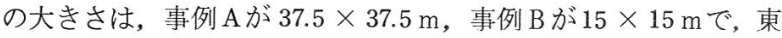
西 $51 \times$ 南北 $51=$ 計 2,601 の格子点の標高データを入力して作成した。

採掘前後の鳥瞰図を比較すると, 事例 $\mathrm{A}$ では, 前面の尾根の切 取りにより，北西方向から風が吹き込み易い状況になることが予

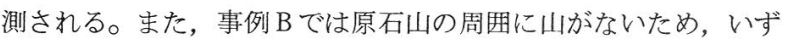
れの方向にも風が吹き抜け易い状況になると予測される。

既往の気象データから推測すると，両事例とも，当該地域は冬

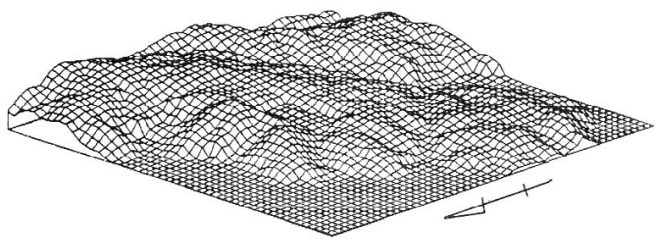

採掘 前

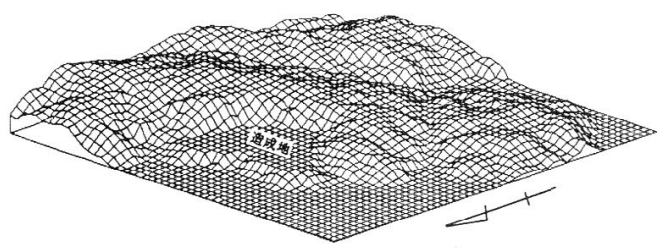

採掘後

Fig. 6 Birds-eye view of pre-mined and mined-out quarry. (Case A)

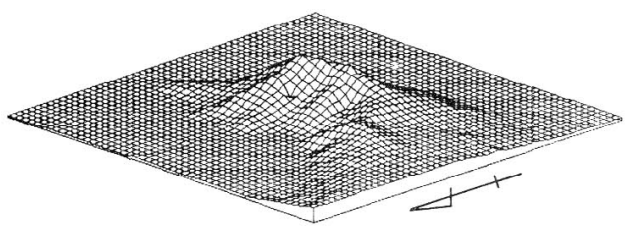

採掘前

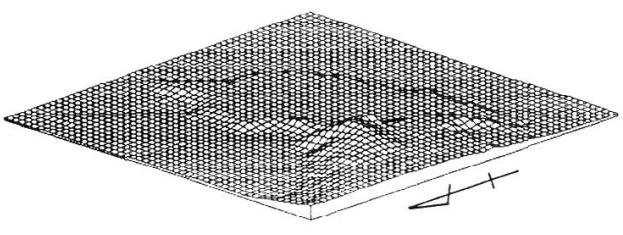

採掘後

Fig. 7 Birds-eye view of pre-mined and mined-out quarry. (Case B)
期は北西，夏期は南東の風が卓越していることから，定性的には 冬期に北西風の影響が現れることが予測される。

\section{5. 風体系変化の定量的予測}

地形と風向との関係を数量的に表現する方法は，現在のところ

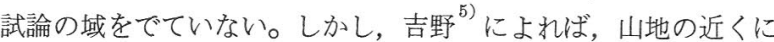
あってその影響のみとめられる地点の年間最多風向頻度 $(F)$ と， 16 万位別の㖽斜の偏差 $(K)$ との間には, $(1)$ 㧍よび(2)式のような関 係が成り立つとしている。

$$
\begin{aligned}
& F_{1}=-193.15 K_{1}+18.33 \\
& F_{2}=-208.25 K_{2}+19.81 \\
& \text { ここで, } \\
& F_{1} \text { : 半径 } 1 \mathrm{~km} \text { の地形について求めた年間最多風向 }(\%) \\
& F_{2} \text { : 半径 } 2 \mathrm{~km} \text { の地形について求めた年間最多風向 }(\%) \\
& K_{1} \text { : 半径 } 1 \mathrm{~km} \text { の地形について求めた傾斜の偏差 } \\
& K_{2} \text { : 半径 } 2 \mathrm{~km} \text { の地形について求めた傾斜の偏差 }
\end{aligned}
$$

(1)，(2)式により求められる年間最多風向頻度 $F$ は，偏差 $K$ が負 で最も大きいものに対応して, 年間の卓越風向頻度を示すもので ある。ところで，既往の気象データによれば，通常，年間を通じ て風向頻度が 0 となる方位がみられる。そこで本研究では，16方 位のうち最も風向頻度が低い方位の頻度を０とする考え方を導入 し，(3)式により16万位の相対風向頻度 $\mathrm{E}$ を求めた。

$$
\begin{aligned}
& E=\frac{100 \times\left(F-F_{\min }\right)}{\sum_{i=1}^{16}\left(F_{i}-F_{\min }\right)} \quad \cdots . . . \\
& \text { ここで, } \\
& F_{\min }: \text { 最小風向頻度 }(\%) \\
& F_{i}: 16 \text { 方位別の風向頻度 }(\%)
\end{aligned}
$$

Table 1 は,採掘前後の風向頻度の計算結果の一例として, 事 例 $\mathrm{A}$ の採掘予定地加占南西に約 $2 \mathrm{~km}$ 離れた地点での計算結果を 示したものである。計算方法を説明すると，まず，基準地点を中 心として16万位に線を引き, 各線上 $2 \mathrm{~km}$ 以内の最高地点と基準 地点との標高差を求める。標高差を $2 \mathrm{~km}$ で割って，16方位別の 傾斜 $(\tan \alpha)$ を算出する。各方位の $\tan \alpha$ と 16 方位のこれらの平

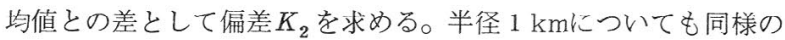
方法で， $K_{1}$ が求められる。この方法により求められる偏差 $K$ は, 地形の傾斜の程度を示すものであり，偏差が負で絶対值が大きい ほど谷が深く刻んでいる（風が吹き易い）ことを意味し，偏差が 正で絶対值が大きいほど高い山がある（風が吹きにくい）ことを 意味している。これらのKの值から，(1)，(2)式により $F$ を求め, (3)式から各方位の相対風向頻度 $E$ を求める。Table 1 の例では, 採掘により東北束方向で最大 $53 \mathrm{~m}$ の標高差の変化がみられ，その 結果，2\%近くの風向頻度の増加が生じると予測される。

Fig.8は，Table 1の採掘前後における風向頻度 $E_{2}$ をもとに 作成した地形因子による風配図である。この地点では，地形的に は北西〜北東および南東〜南南東方向から風が吹き込み易く，東 方向からは風が吹きにくいことがわかる。採掘による地形改变に 伴い北西〜北東方向抽よび南東〜南南東方向の風向頻度が増加し， 南〜西北西方向の風向頻度が減少すると予測される。

つぎに, 原石山周辺地域の地形因子による卓越風向の変化を全 体的に把握するために，1/25,000の地形図に原石山を中心とし て $200 \mathrm{~m}$ 毎に東西 22 , 南北 25 のッシニを切り,その格子点計 550 点について半径 $2 \mathrm{~km}$ で16方位の採掘前後の最高点を求めて, 風 向頻度の計算を行った。

Fig.9, Fig.10は, 上記の力法で求めた風向頻度より, 各地 点の採掘前後の卓越風向を表したものである。図中の矢印は, そ 
Table 1 Example of calculation results of wind direction frequency for pre-mined and mined-out conditions.

基準地点標高 : $2 \mathrm{~m}$

\begin{tabular}{|c|c|c|c|c|c|c|}
\hline 風 向 & $\begin{array}{c}\text { 最高点 } \\
(\mathrm{m})\end{array}$ & $\begin{array}{c}\text { 高低差 } \\
(\mathrm{m})\end{array}$ & $\tan \alpha$ & $K_{2}$ & $F_{2}(\%)$ & $E_{(\%)}$ \\
\hline $\mathrm{N}$ & 2 & 0 & 0 & -0.01975 & 23.92 & 8.43 \\
\hline NNE & 2 & 0 & 0 & -0.01975 & 23.92 & 8.43 \\
\hline NE & 2 & 0 & 0 & -0.01975 & 23.92 & 8.43 \\
\hline ENE & 155 & 153 & 0.0765 & 0.05675 & 7.99 & 0 \\
\hline $\mathrm{E}$ & 126 & 124 & 0.0620 & 0.04225 & 11.01 & 1.60 \\
\hline ESE & 105 & 103 & 0.0515 & 0.03175 & 13.20 & 2.75 \\
\hline $\mathrm{SE}$ & 2 & 0 & 0 & -0.01975 & 23.92 & 8.43 \\
\hline $\mathrm{S} \mathrm{SE}$ & 2 & 0 & 0 & -0.01975 & 23.92 & 8.43 \\
\hline S & 62 & 60 & 0.0300 & 0.01025 & 17.68 & 5.12 \\
\hline S SW & 45 & 43 & 0.0215 & 0.00175 & 19.44 & 6.06 \\
\hline SW & 35 & 33 & 0.0165 & -0.00325 & 20.49 & 6.61 \\
\hline WSW & 35 & 33 & 0.0165 & -0.00325 & 20.49 & 6.61 \\
\hline W & 45 & 43 & 0.0215 & 0.00175 & 19.44 & 6.06 \\
\hline WNW & 42 & 40 & 0.0200 & 0.00025 & 19.76 & 6.22 \\
\hline NW & 2 & 0 & 0 & -0.01975 & 23.92 & 8.43 \\
\hline NNW & 2 & 0 & 0 & -0.01975 & 23.92 & 8.43 \\
\hline
\end{tabular}

\begin{tabular}{|c|c|c|c|c|c|c|}
\hline 風 向 & $\begin{array}{c}\text { 最高点 } \\
(\mathrm{m})\end{array}$ & $\begin{array}{c}\text { 高低差 } \\
(m)\end{array}$ & $\tan \alpha$ & $K_{2}$ & $\left.{ }^{F} \%\right)$ & $E_{2}(\%)$ \\
\hline $\mathrm{N}$ & 2 & 0 & 0 & -0.01809 & 23.58 & 8.83 \\
\hline NNE & 2 & 0 & 0 & -0.01809 & 23.58 & 8.83 \\
\hline NE & 2 & 0 & 0 & -0.01809 & 23.58 & 8.83 \\
\hline ENE & 102 & 100 & 0.0500 & 0.03191 & 13.17 & 1.71 \\
\hline $\mathrm{E}$ & 126 & 124 & 0.0620 & 0.04391 & 10.67 & 0 \\
\hline ESE & 105 & 103 & 0.0515 & 0.03341 & 12.85 & 1.49 \\
\hline $\mathrm{SE}$ & 2 & 0 & 0 & -0.01809 & 23.58 & 8.83 \\
\hline S S E & 2 & 0 & 0 & -0.01809 & 23.58 & 8.83 \\
\hline S & 62 & 60 & 0.0300 & 0,01191 & 17.33 & 4.56 \\
\hline S SW & 45 & 43 & 0.0215 & 0.00341 & 19.10 & 5.77 \\
\hline SW & 35 & 33 & 0.0165 & -0.00159 & 20.14 & 6.48 \\
\hline WSW & 35 & 33 & 0.0165 & -0.00159 & 20.14 & 6.48 \\
\hline W & 45 & 43 & 0.0215 & 0.00341 & 19.10 & 5.77 \\
\hline WNW & 42 & 40 & 0.0200 & 0.00191 & 19.41 & 5.98 \\
\hline NW & 2 & 0 & 0 & -0.01809 & 23.58 & 8.83 \\
\hline NNW & 2 & 0 & 0 & -0.01809 & 23.58 & 8.83 \\
\hline
\end{tabular}

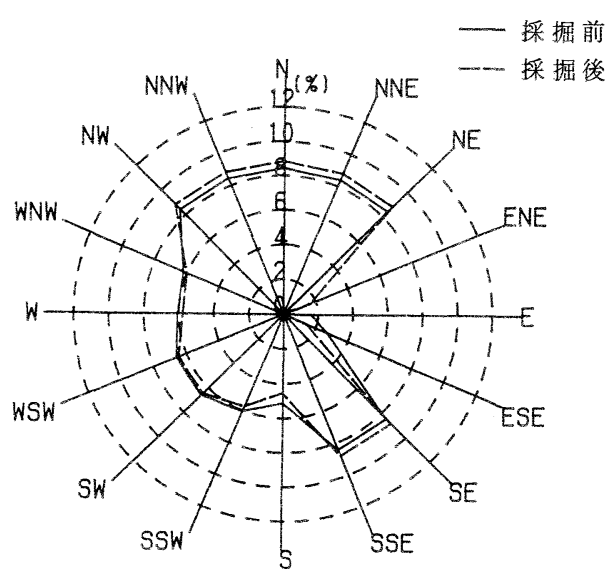

Fig. 8 wind rose drawn by topography factor.

の方向への風の吹き易さを示している。採掘による地形改変に伴 几て卓越風向が変化する地点については, 採掘後の卓越風向を太 い矢印で示した。図をみると，地形と風の吹き込及易さが一致し ており，今回採用した定量的予測法が適していることがわかる。

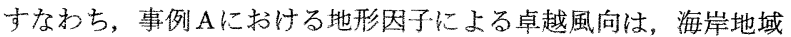
では南から北に吹き易く，市街地では西から東に吹き易い傾向を 示している。また, 山地部では尾根や谷に沿って平地の方向から 吹き易い傾向を示している。事例 B の場合には，点在する山塊に
対応して卓越風向は複雑に変化しているが, 地形と卓越風向との 関係は一致した傾向を示している。

採掘前後での卓越風向を比較すると, 事例 Aでは採掘予定地の 東側から南側にかけて約 $2 \mathrm{~km}$ の範囲の 22 地点で風向変化がみら

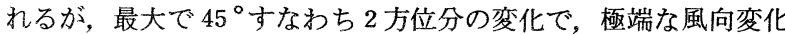
はみとめられない。事例 Bでは，採掘場の西から南西部にかけて 31 地点で卓越風向の変化がみられ，最大では $112.5^{\circ}$, すなわち 5

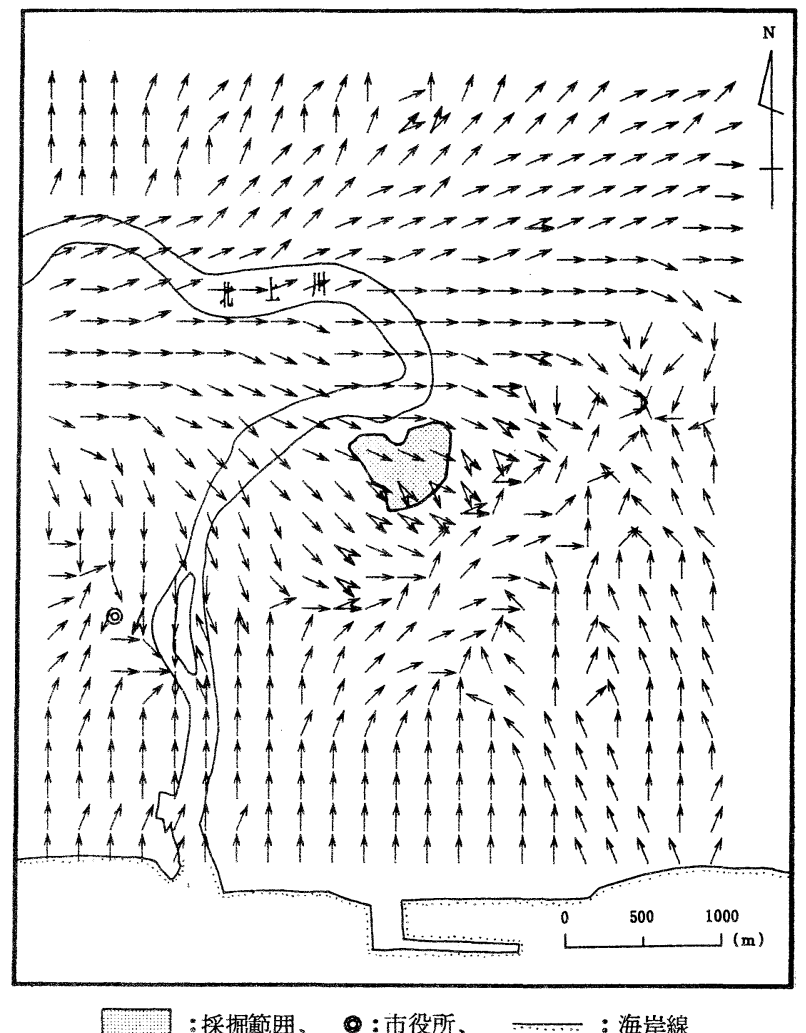

Fig. 9 Prevailing wind direction of pre-mined and mined-out condition. (Case A)

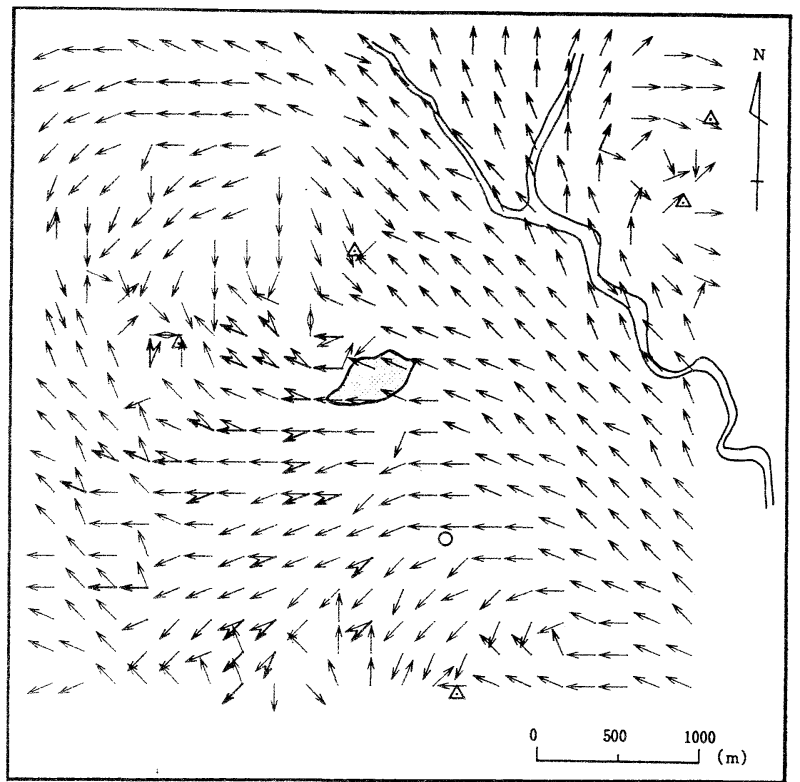

: 採掘範囲、 $\mathrm{O}$ : 町役場、 $\Delta$ : 山頂

Fig. 10 Prevailing wind direction of pre-mined and mined-out condition. (Case B) 
方位分の風向変化がみられるなど，事例 $\mathrm{A}$ に比べ広範囲でかつ大 きく風体系変化が生じると予測される。

Fig.11, Fig.12 は, 採掘による地形改变に伴う卓越風向頻 度の変化を比で表したものである。図中の数值は，採掘前に対す る採掘後の卓越風向頻度の比で, 1.00 以上は採掘により風向頻度 が増加することを表し， 1.00 末満は逆に減少することを表してい る。また, 太文字は卓越する風向が変化する地点を示している。 卓越風向頻度の変化は, 事例 A では計 137 地点でみられ, 最高で

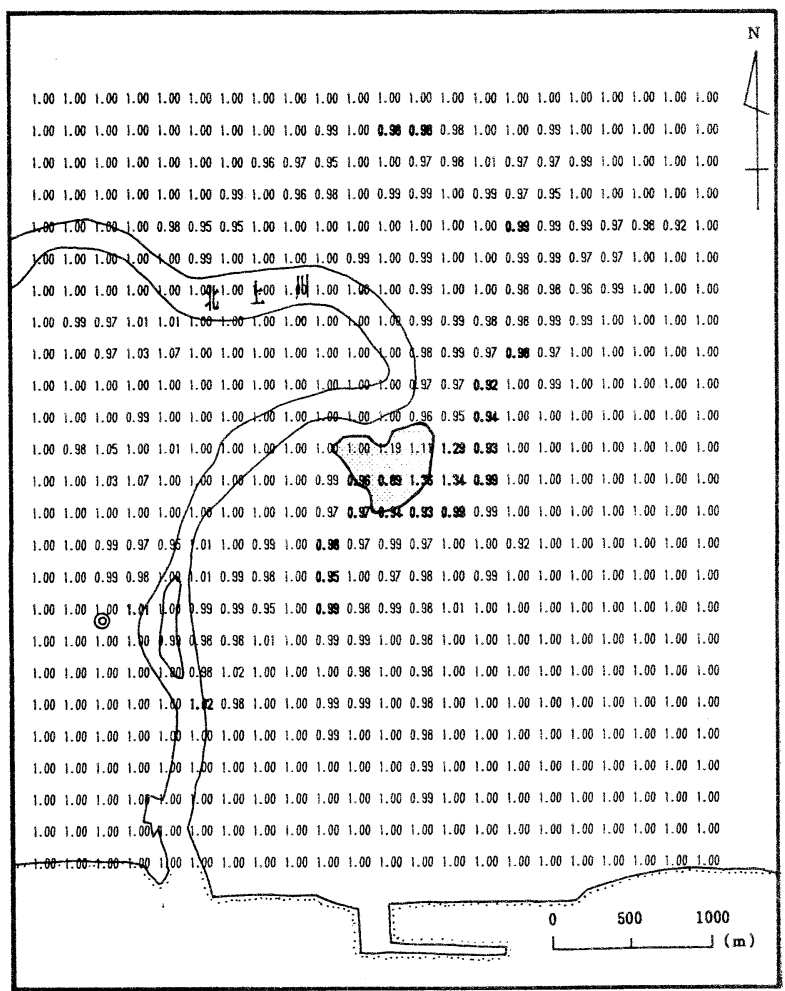

: 採掘範囲、市役所、

Fig. 11 Ratio of prevailing wind direction frequency of pre-mined and mined-out condition. (Case A)

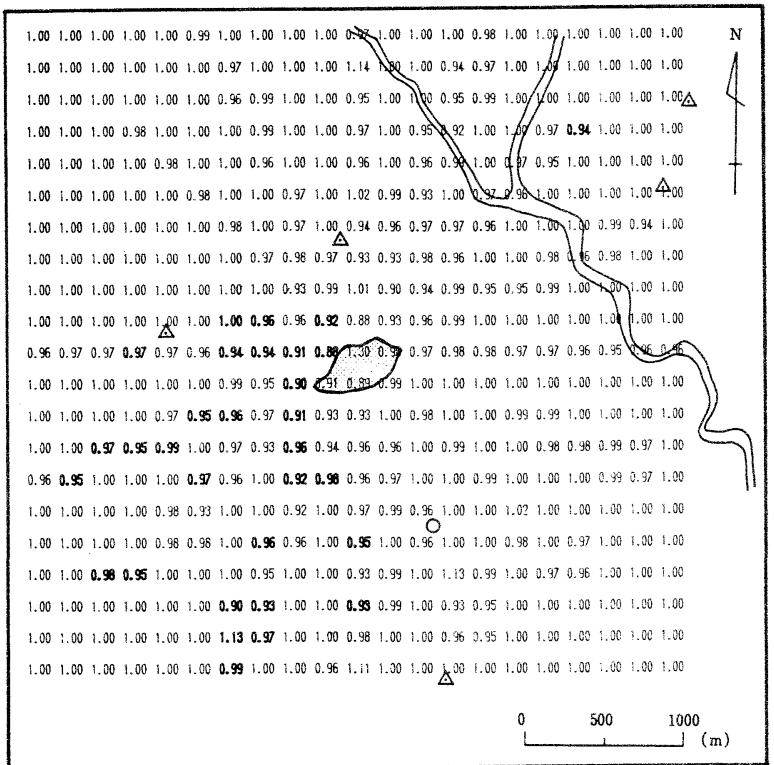

—:採掘範囲、 $\mathrm{O}$ : 町役場、 $\Delta:$ : 頂

Fig. 12 Ratio of prevailing wind direction frequency of pre-mined and mined-out condition. (Case B)
$36 \%$ 頻度増加，11\%の頻度減少が生じると予測される。また, 事例 $\mathrm{B}$ では，175 地点で卓越風向頻度の変化があり, 最高で $30 \%$ の頻度増加, $12 \%$ 頻度減少が生じると予測された。両事例とも， 卓越風向が変化する地点では変化しない地点に比べて, 風向頻度 の変化が大きい傾向がみられる。

風向変化の定量的予測結果をまとめると, 事例 $\mathrm{A}$ の原石山周辺 地域では, 地形的には西から北寄りの風が吹き易く, この地域で は夏期は南東, 冬期は西北西の風向頻度が高いことから, 採掘場 南東部で冬期に採掘による風体系変化の影響が現れ易いと予測さ れる。しかし，この地域を吹く風の多くが微風であることや，影 響する地域が山側であることなどを考慮すると, 生活環境への影 響は少ないものそ判断される。一方，平坦部に山塊が点在する事 例 Bでは, 原石山の採掘により採掘場南西部の広い範囲で風向変 化が起こると予測される。周辺地域のほとんどが農耕地で住宅も 点在していることから, 農作物や生活環境への影響は大きいと考 えられる。

\section{6. 森林の減風効果の検討}

露天採掘に伴う風体系变化を予測する場合, 伐採される森林が ぞの程度の減風効果を有しているかを検討する必要がある。そこ で, 森林の減風効果について調べるために, 岩手県零石町の小岩 井農場において, 防風林前後の各点で風向, 風速の観測を行った。 減風効果を調べた同農場の防風林は杉の植生林で，その規模は， 樹高約 $13 \mathrm{~m}$, 植生間隔約 $3 \mathrm{~m}$, 長さ約 $500 \mathrm{~m}$, 幅約 $60 \mathrm{~m}$ である。

Fig.13は, 観測結果をもとに, 相対風速と高倍距離との関係 を示したものである。な拉，相対風速とは，防風林の風上側で樹 高の15倍の距離の地点におけする風速を基準とし, 各観測点での風 速を比として表したものである。また, 高倍距離とは, 防風林か らの距離を樹高の倍数で表したもので, 風上側を負, 風下側を正 とした。

図より，風上側一 $10 H$ での相対風速は平均で $80 \%$ 程度で, す でに減風効果が現れておう, 防風林に近づくにつれて相対風速は 減少していることがわかる。風下側では, 相対風速はさらに小さ くなり, 減風効果がより顕著に現れている。風下側 $3 H$ で相対風 速は最小となるが，防風林から離れるにしたがって，相対風速は 再び増加し, 減風効果が低下していくことがわかる。通常, 風下 側での減風効果は $20 H$ 程度までであるといわれている

このように, 防風林による減風効果は明らかにみとめられ, 相 対風速が最小となる $3 H$ では, 風速が半分以下に低下し, また, $10 H$ でも $70 \%$ 程度に減少することが明らかとなった。防風林の減 風効果は, 樹高, 風の性質, 防風林の構造のほかに, 防風林前後 の状態などによって变化するといわれている7)。これらの要因の うち, 今回減風効果を調査した小岩井農場の防風林と, 両事例の 原石山の森林とは，樹高や植生間隔はほぼ類似したものといえる。 しかし，森林周辺の状態に関しては，かなり異なっている。すな わち，小岩井農場では周辺が平坦な牧草地であるのに対して，当

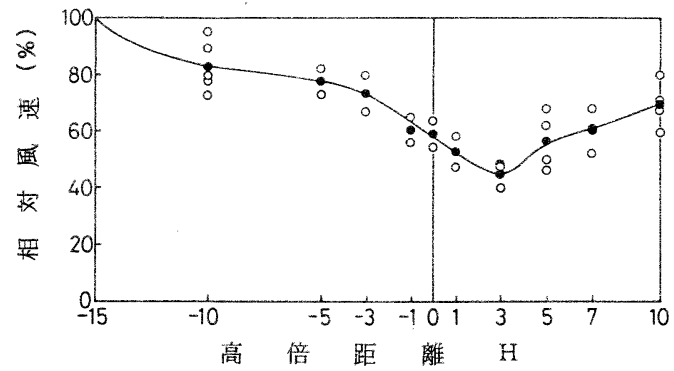

Fig. 13 Relationship between relative wind speed and proportion of distance to height of forest. 
該地域周辺は丘陵状になっており，民家などの風の流れを乱す障 害物も多く, 地表の状態, 斜面の傾斜, 付近の山地の状態など微 気候の因子が異なっている。したがって，小岩井農場における観 測結果をそのまま当該地域に当てはめることはできない。例えば, 防風林の減風効果は, 周辺の地形々防風林の設置箇所との関係で 大いに異なるといわれている。小岩井農場では防風林は平地に設 置されているのに対して, 当該地域では尾根部分にも森林が植生

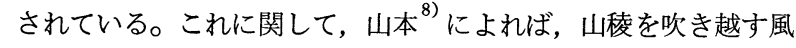
に対しては, 山頂部の稜線に防風林を設置した場合には, 風下側 の減風効果は平地に比べてはるかに大きく，かつ広い領域が保護 されるといわれている。よって, 先の観測結果以上の減風効果が あることも考えられる。

いずれにしても, 露天採掘に伴う森林の伐採は, 森林が有して いる防風林としての機能を奪うものである。特に稜線部の樹林の 伐採は, 風向变化や風速増加などの風体系変化に大きく影響する ことが考えられる。したがって, 尾根部にまで及ぶ採掘は, 森林 の伐採を含めて周辺地域の風体系に及ぼす影響が大きいことを十 分に考慮して，採掘計画を立てる必要がある。

\section{7. 結言}

地形改变を伴う大規模な露天採掘が周辺地域の風体系に及ぼす 影響について，2つの事例を取り上げ検討した。その結果を要約 すると以下の通りである。

1) 露天採掘に伴う地形改変状況をコンピュータグラフィック スによりシミュレーションし, 風向変化を定性的に予測する方法 を確立した。

2 ）地形と風向頻度との関係を数量的に表現する方法を用いて, 地形改変に伴う風向頻度変化を定量的に予測する方法を確立した。

3）森林の減風効果を調べ, 伐採による風速への影響を推定し 得る可能性を示した。
4）尾根の切取りが比較的少くない事例 Aでは, 風体系変化の 影響は生活環境へは直接的には少ないと予測された。一方, 平坦

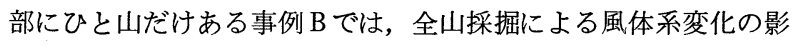
響は広範囲かつ大きなものになるので, 防風林帯を残すなど何ら かの防風対策が必要であるという結論になった。

尾根部にまで及ぶ採掘や全山採掘方式は, 大量の原石採取や跡 地利用などの利点を有する反面, 周囲の環境に及ぼす影響も大き いと想定される。今回の研究結果からも, 大幅な地形改変を伴う 露天採掘が周辺地域の風体系に影響を及ぼすことが明らかである。 したがって, 露天掘鉱山の開発計画策定にあたっては, 風体系変 化の予測を含め, 様々な観点から環境影響評価を十分に行う必要 があるといえる。

最後に, 本研究に協力された岩手大学工学部主濱英夫技官なら びに大学院生の海老名弘明氏 ( 現釧路労動基準監督署) に感謝の 意を表する。また, この研究の一部は, 文部省科学研究費補助金 一般研究 (C) ( 課題番号 03650511 )により行われたことを付記し, 謝意を表する。

\section{引用 文 献}

1) 中井 裕: 新版碎石, p.97-107, (1990), 技術書院(東京)

2) 吉野正敏: 小気候, p.1-7, (1986), 地人書館 (東京)

3 ) 白岩隆己・田中正央・藤森博美 : 実例パソコン立体図, p.71-118, (1986), 講談社 (東京)

4) 野上道男・杉浦芳夫 : パソコンによる数理地理学演習, p.28-29, (1986), 古今書院 (東京)

5) 吉野正敏: 地理学評論, Vol.25, p.103-108, (1952)

6）真木太一：風害と防風施没，p.174-180, (1987) , 文永堂出 版 (東京)

7) 羽生寿郎・中川行夫・山本良三・坂上 務・矢吹万寿・堂腰 純: 農業気象学, p. 158-169, (1978), 文永堂出版 (東京)

8）山本良三: 日作紀, Vol.24, p.217-218, (1956) 